\title{
Changes in body composition during pregnancy and lactation
}

\section{By J. J. Robinson, Rowett Research Institute, Bucksburn, Aberdeen $A B 29 S B$}

Changes in the maternal body during reproduction are characterized by their diversity and this holds true for comparisons within as well as between species. The weights of some organs and tissues increase whereas others decrease and there is considerable variation in the magnitude of these changes (Hytten \& Leitch, 1971). For interspecies comparisons the enormous differences in the quantitative expression of pregnancy and its failure to conform to any clear-cut generalization (Blaxter, 1964) makes it difficult to propose a unifying hypothesis for its effects on the maternal body. Even for lactation, a physiological state for which dimensional analysis using allometric equations yields some useful generalizations regarding its metabolic demands, species differences still exist (Blaxter, 197r; Hanwell \& Peaker, 1977). Nonetheless there are many instances in which the changes in composition are broadly understandable in terms of the changing function of the maternal body and can be accepted as a general feature of reproduction. Thus, even if it were desirable to do so, it would be impossible to devise a nutritional regimen which would simultaneously permit normal reproduction and maintain maternal body composition unchanged throughout. Rather, the aim must be to produce balance in the composition of the body over the breeding cycle as a whole.

There are many examples of the preceding principle in action. The seasonal cycles in the food intake of the red deer and feral sheep, although in approximate synchrony with their nutrient needs are not exactly so and body fat stored before mating is lost in late pregnancy and early lactation (Mitchell et al. 1976; Milner \& Gwynne, 1974). The grey seal provides an extreme example; in the few weeks following the birth of her pup she depends entirely on body reserves accumulated during pregnancy for the production of milk which contains over $50 \%$ fat and which promotes a daily live-weight gain in her pup of $\mathrm{I} \cdot 5 \mathrm{~kg}$ (for review, see Widdowson, 1976, 1981). A similar phenomenon, albeit expressed in a much less spectacular way, occurs in a number of species, including humans, that tend to deposit fat in their bodies during pregnancy and lose it during lactation (Widdowson, 1976). Such examples portray the notion of an anticipatory role for the maternal body during reproduction. In reality they are responses to a sequence of complex neuroendocrine and biochemical stimuli that follow on from conception and which are modified in their expression by the constraints imposed by the environment.

\section{Specific effects of pregnancy}

Pregnancy anabolism. When the pregnant of a number of species are given the same amounts of food as unmated controls, higher weight gains and nitrogen 
retentions have been noted. These manifest themselves remarkably early in pregnancy (sheep, Rombauts, 1959; pigs, Elsley et al. 1966; rats, Campbell, et al. I974) and at levels well above the estimates of the net gains of the products of conception at this time. Such observations gave rise to the notion that pregnancy stimulates the growth of animals that have not achieved their mature size by enhancing the net gain of lean tissue in the maternal body (Salmon-Legagneur, 1965; Heap \& Lodge, 1967). It has been pointed out, however, by Hovell et al. (r977) that any meaningful interpretation of the lasting effects of pregnancy on maternal growth must take into account the large losses of $\mathbf{N}$ that occur in the urine during the immediate post-partum period. When Hovell et al. (1977) delayed the slaughter of gilts to $9 \mathrm{~d}$ after farrowing, they could find no convincing evidence for a permanent anabolic effect of pregnancy even though the gilts had not been allowed to lactate. Indeed, when they examined the earlier information on which the idea of an anabolic effect in the gilt was based, they concluded that the increase in the post-partum losses of urinary $\mathrm{N}$ that accompany the regression of the uterus, abdominal muscle and mammary tissue, could equal all the pregnancy anabolism.

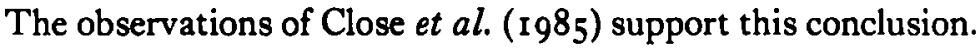

Blood volume. Although a minor component of the weight change associated with pregnancy, the shift in blood volume is an important physiological adaption of the maternal organism (Hytten \& Leitch, r97I). While there is general agreement that pregnancy enhances blood volume (man, Hytten \& Paintin, 1963; sheep, Barcroft et al. 1939; cow, Reynolds 1953; pig, Anderson et al. 1970) the results suggest considerable species diversity in the pattern of increase. Man and the bovine exhibit a steady increase up to week 34 and parturition respectively, the pig an initial decline followed by a continuous rise to parturition, and the sheep rapid increases at the beginning and end of pregnancy with a plateau in between. There is no evidence in the pig and sheep of an effect of fetal weight or litter size on the increase in blood volume as has been observed in man (Duffus et al. 1971; Hytten \& Leitch, 1971).

Mammary tissue. Using the beginning of pregnancy as a baseline, Anderson (1975) brought together information for a number of species on the relative amounts of mammary tissue growth during pregnancy and lactation. In sheep, whose relatively long gestation period of 5 months provides time to grow the lobule-alveolar epithelial cell system that is needed for maximal milk yield, $98 \%$ of mammary growth occurs in pregnancy (Anderson, 1975) and the quantity of mammary tissue at birth is directly proportional to litter size (Robinson et al. 1978). The value of $98 \%$ for sheep contrasts with 60,67 and $78 \%$ for the rat, rabbit and mouse respectively, three species in which the intensity of the sucking stimulus would appear to play a significant role in mammary growth.

Liver. It is well known that the liver is highly sensitive to transitory shifts in nutritional and physiological states and much of the literature on the pregnant of all species reflects this. Lodge \& Heaney (1973) recorded ewe liver weights at the end of pregnancy that were $23 \%$ greater than those for unmated pair-fed controls but one-third of this was due to fat infiltration. One of the most informative 
studies, albeit probably species specific in its findings on the effects of pregnancy on the liver, is that of Campbell et al. (1974). In a comparison between pregnant and non-pregnant rats given the same amount of food they showed that between days 12 and 18 of pregnancy there were increases in the order of $6-10 \% / \mathrm{d}$ in liver weight, total RNA, total DNA and mean liver cell nuclear volume. Histological studies confirmed that the increase in weight was associated both with liver cell enlargement and with increased rates of cell division.

Gastrointestinal tract. Since pregnancy in the ewe is accompanied by a decrease in the time that food is retained in the rumen (Faichney $\&$ White, I980) and a consequent increase of about $15 \%$ in the quantity of amino-N reaching the abomasum (Gonzalez et al. 1985), specific effects of pregnancy on the weights of the empty organs of the alimentary tract might be expected. Indeed, Fell et al. (1972) observed that the average weights of the abomasum and small intestine were higher by 24 and $45 \%$ respectively in ewes killed during the last 6 weeks of pregnancy than in unmated controls.

\section{Specific effects of lactation}

Unlike the gradual increase in the metabolic demands that accompany pregnancy, those for lactation are immediate and much larger and their effects on the maternal body may reflect the associated rapid change in food intake. What little evidence there is suggests that the blood-volume changes noted in pregnancy are sustained or even slightly increased in early lactation (Anderson et al. 1970). For species as diverse as the sheep and rat there are further increases above those of pregnancy in the weight, size and $\mathrm{N}$ content of the walls of the abomasum and small intestine (Fell et al. 1963, 1964, 1972). In sheep these occur despite severe losses in carcass weight and are accompanied by increases in the weight and $\mathrm{N}$ content of the reticulo-rumen. It would appear that these changes, together with an increase in the mucosal surface area (Boyne et al. 1966), enable the lactating ewe to digest its food to the same extent despite rapid increases in feed intake (Cowan et al. 1980). In the ewe the liver also increases in size during lactation, due both to hyperplasia and to hypertrophy (Campbell \& Fell, 1970). Although these changes may be in response to an increase in appetite, Fell \& Campbell (1974) observed a rise in the number of necrotic liver cells immediately after lambing and suggested that their demise, which may be the result of hormone changes at parturition, could trigger the post-parturient hyperplastic response of the liver.

\section{Modifying influences of nutrition}

The changes in the tissues and organs of the maternal body that accompany reproduction are modified by dietary factors. For example, food restriction reduces the magnitude of the blood volume increase in pregnancy (sheep, Robinson et al. 1978; rat, Rosso \& Streeter, 1979) and the same holds true for the liver and gut (sheep, Cowan et al. 1979). In rats a marginal protein deficiency reduces liver hypertrophy but not hyperplasia, whereas a severe deficiency reduces both (Zartarian et al. 1980). Despite these modifications the maternal body usually 


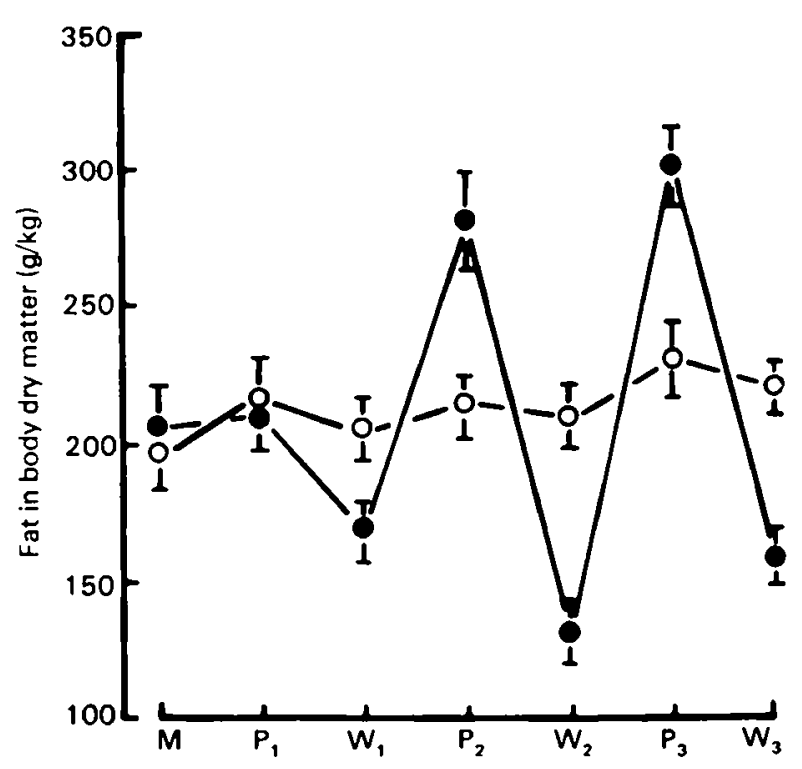

Fig. 1. Fat in the bodies of virgin $(O)$ and mated $(\odot)$ mice fed ad lib. for three successive reproductive cycles. $M$, Ist mating; $P_{1}, P_{2}, P_{3}=$ Ist, 2nd and $3^{\text {rd }}$ parturitions respectively; $W_{1}, W_{2}$, $W_{3}=1 s t$, 2nd and 3 rd weanings-rematings respectively (plotted from values presented by Johnson, 1973).

retains the ability to sustain normal reproduction and it is only on feeding regimens that are well below or grossly in excess of current needs that fetal growth and mammogenesis are impaired (rats, Naismith, 1969; sheep, Robinson, 1977; cattle, Little \& Kay, 1979). The less-extreme nutritional regimens are accommodated by depletion and repletion of body reserves. It is these changes that are of particular interest.

Mention has been made already of the tendency of a number of species, man included, to deposit fat during pregnancy in response to an increase in food intake and to lose it and, in some cases, even more, in the ensuing lactation. The observations of Johnson (1973) for mice fed ad lib. are plotted in Fig. I and provide a forceful illustration of this point. Recently, Moore \& Brasel (1984), working with rats, posed the question, what happens to the fat deposited in pregnancy in animals that do not lactate? Their observations, albeit restricted to one reproductive cycle, showed that the fat was still there at $42 \mathrm{~d}$ post partum, prompting the notion that repeated pregnancy in the absence of lactation may cause obesity. Indeed, from the results of a subsequent experiment, Moore et al. (1984) suggested that the feeding of high-fat diets could predispose rats to obesity even in the presence of lactation. Further experiments will be required to substantiate these hypotheses; so too will investigations to verify that the accretion of fat persists right up to the end of pregnancy. Although there is a large body of literature (for review, see Vernon \& Flint, 1984 ) to indicate that it does, there is also evidence that the anabolic phase ends around day 16 (Knopp et al. 1973). 
The idea of an initial anabolic phase followed by a catabolic one towards the end of pregnancy is not restricted to lipid metabolism. Naismith \& Morgan (1976) put forward a similar hypothesis for protein accretion in the rat and demonstrated that the feeding of a high-protein diet in early pregnancy could alleviate the detrimental effects on placenta and fetal size of low-protein feeding in late pregnancy. Comparison of the pattern of total $\mathrm{N}$ retention observed by Elsley et al. (1966) for gilts with that for accretion in the products of conception would suggest a similar biphasic response in protein metabolism at the constant feeding level employed.

For a number of species the restrictions in food intake imposed by the environment not only prevent the deposition of nutrients in the maternal body during pregnancy but actually induce substantial losses. One of the best examples of this is the change in the composition of the maternal body of Blackface ewes kept under hill conditions in Scotland (Fig. 2). Throughout virtually the whole of pregnancy and into the early part of lactation the maternal body is continuously
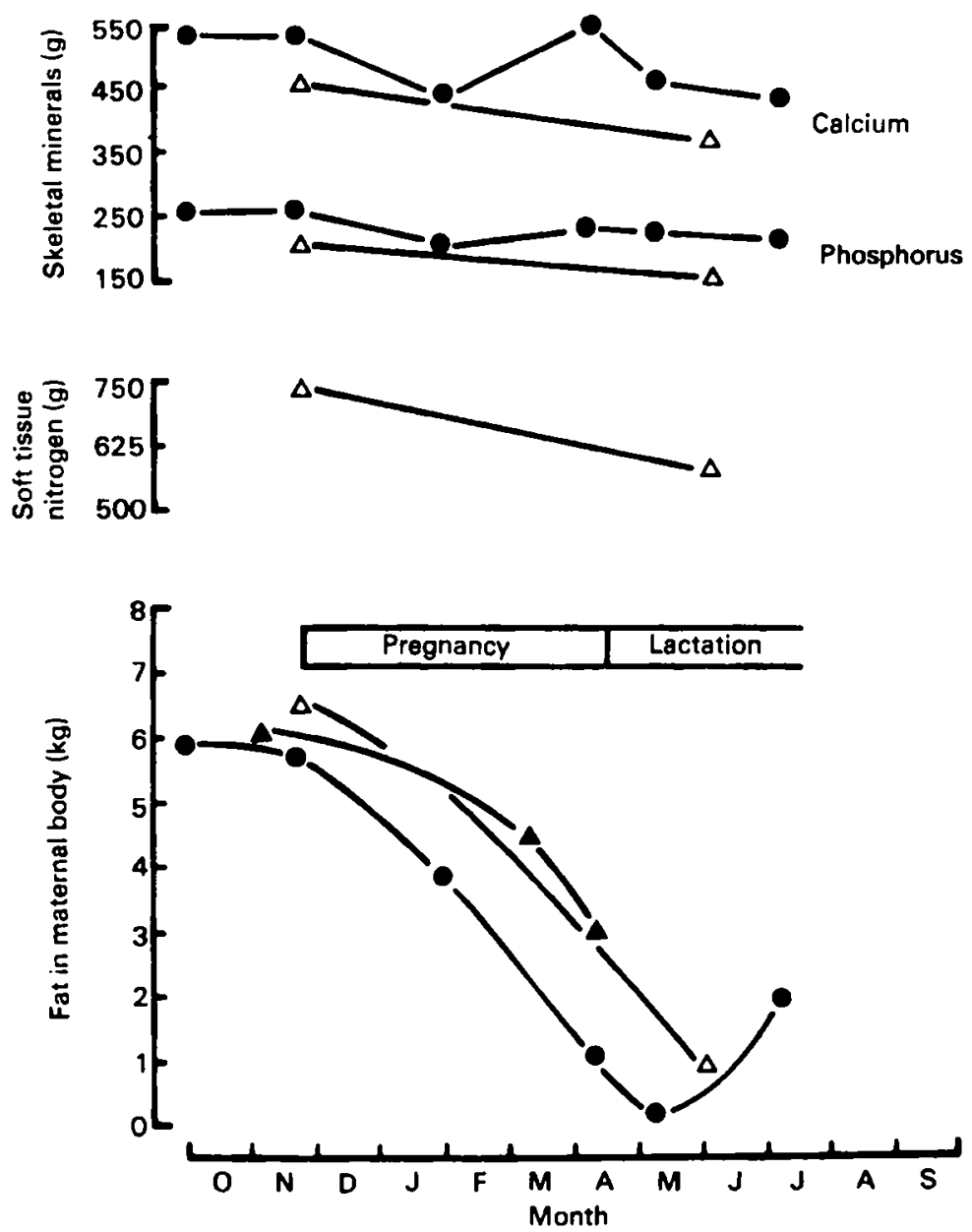

Fig. 2. Changes in the composition of the maternal body of Scottish Blackface ewes grazing hill pastures. Sources: (O), Field et al. (1968); (A), Russel et al. (I968); ( $\Delta$ ), Sykes \& Field (I974). 
losing lipid, soft-tissue $\mathbf{N}$ and skeletal minerals. In principle the loss of lipid, spectacular though it is, merely represents the use of a product, most of which is surplus to the needs of the ewe for functional competence. The $20 \%$ loss of tissue $\mathrm{N}$ is a different matter. It not only implies a degree of protein deficiency directly detrimental to the normal protein metabolism of the body but it may also induce an inevitable loss of calcium from the skeleton as a consequence of the bone matrix erosion that accompanies protein deficiency (Sykes et al. 1973; Sykes \& Geenty, I985).

\section{Composition of weight change}

An increase in tissue hydration and particularly in the amounts of extracellular fluid is a feature of pregnancy in a number of species including man (Hytten \& Leitch, 1971), sheep (Foot, 1969), cattle (Degan \& Young, 1980), pigs (Lodge et al. 1979) and rats (Kanto \& Clawson, 1980). In some studies the increase is more than can be accounted for by the gains in the udder and blood (sheep, Robinson et al. 1978) but this is not always the case (pigs, Shields \& Mahan, 1983). The hydration can persist into lactation (sheep, Foot et al. 1979; Cowan et al. 1980; pigs, Zoiopoulos et al. 1983) or if absent in pregnancy, can occur in lactation (mice, Johnson, 1973). For some animals the magnitude of the shift in tissue hydration during pregnancy is too small to have any noticeable influence on the energy value of maternal weight change (Agricultural Research Council, 1980) but for others this is not so. In very prolific ewes the increase in the water:protein value of the maternal body can be as high as $10 \%$ during pregnancy and when accompanied by losses in body fat can give rise to estimates for the energy value of maternal weight change that otherwise would be regarded as unrealistically high (Robinson $e t$ al. 1978).

The preceding example illustrates the dangers of relying on weight-gain targets during pregnancy as indices of adequate nutrition. The same holds true for lactation, yet this is a physiological state for which changes in body-weight are often assumed to reflect trends in energy balance. Some indication of the magnitude of the variation in the energy content of weight change during early lactation was obtained by Cowan et al. (1980, 1981) in comparative slaughter experiments with ewes. Their estimates, which were obtained between the ist and 6th week of lactation, varied from 24 to $90 \mathrm{MJ} / \mathrm{kg}$ weight change depending on diet type and ewe body condition. The corresponding range expressed on empty-bodyweight change was -8 to $50 \mathrm{MJ} / \mathrm{kg}$.

A striking example of the ability to manipulate, by dietary means, the composition of weight loss during lactation is seen in the low-level feeding of a high-protein diet. The results obtained from such a study are given in Table I and provide a clear illustration of the ability of the lactating ewe to use large amounts of body fat without any major shifts in protein or mineral status provided, of course, the diet supplies adequate amounts of these constituents. This contrasts with the values presented in Fig. 2 for hill ewes in which the depletion of all the major constituents of their bodies reflects their general undernutrition. The values 
Table 1. The chemical composition of the empty bodies of lactating eqves receiving $240 \mathrm{~g}$ crude protein (nitrogen $\times 6 \cdot 25$ ) and 16 Mf metabolizable energy daily (from Cowan et al. 1979)

\begin{tabular}{|c|c|c|c|c|c|c|}
\hline \multirow{2}{*}{$\begin{array}{l}\text { Day of } \\
\text { lactation }\end{array}$} & \multicolumn{5}{|c|}{ Wt of body components $(\mathrm{kg})$} & \multirow{2}{*}{$\begin{array}{l}\text { Energy content } \\
\text { of empty-body-wt } \\
\text { change } \\
(\mathrm{MJ} / \mathrm{kg})\end{array}$} \\
\hline & Empty body & Fat & Protein & Water & Ash & \\
\hline $\begin{array}{l}12 \\
41\end{array}$ & $\begin{array}{l}47 \cdot 3 \\
42 \cdot 6\end{array}$ & $\begin{array}{l}9 \cdot 2 \\
2 \cdot 3\end{array}$ & $\begin{array}{l}9 \cdot 3 \\
8 \cdot 9\end{array}$ & $\begin{array}{l}27 \cdot 5 \\
29 \cdot 7\end{array}$ & $\begin{array}{l}1 \cdot 7 \\
2 \cdot 2\end{array}$ & $\begin{array}{l}59 \\
33\end{array}$ \\
\hline 111 & $4 I \cdot 5$ & $I \cdot 2$ & $9 \cdot 2$ & 29.4 & $2 \cdot 3$ & \\
\hline
\end{tabular}

presented in Table I also reveal another interesting feature of lactation in the ewe, namely that it is only during early lactation and, as a consequence of the rapid loss of body fat coupled with tissue hydration, that unusual values for the energy content of maternal weight loss (I. 5 times that of fat) occur. Thereafter they are of the same order of magnitude as those obtained with non-pregnant, non-lactating sheep fed below maintenance.

These changes in the composition of the maternal body and their manipulation by nutrition are not specific to sheep nor indeed to ruminants. The ad lib.-fed mice of Johnson (1973) lost fat during lactation (Fig. I) but gained substantial amounts of protein. In the experiment of Kanto \& Clawson ( 1980 ), rats on a low plane of nutrition in late pregnancy followed by a high-plane during lactation put back, while suckling, some of the protein lost during gestation but withdrew a small amount of fat. More recently Naismith et al. (1982) observed a $60 \%$ loss of total body fat during lactation accompanied by a small gain in body protein in rats given a high-protein diet.

Table 2. Estimates for a number of species of the rates of fat loss from the body during lactation

\begin{tabular}{|c|c|c|c|c|}
\hline & & Daily & of fat & \\
\hline & Wt (kg) & g & $\mathrm{g} / \mathrm{kg} \mathrm{W} \mathrm{W}^{0.75}$ & Source \\
\hline Mouse & 0.022 & 0.044 & 0.8 & Johnson (1973) \\
\hline Rat & 0.275 & I. 54 & $4 \cdot 1$ & Naismith et al. (1982) \\
\hline Rabbit & 3.85 & $7 \cdot 5$ & $2 \cdot 7$ & Partridge et al. (1983) \\
\hline Sheep & 70 & 200 & $8 \cdot 3$ & Cowan et al. (1982) \\
\hline Man & 70 & 30 & I. 2 & Widdowson (1976) \\
\hline Pig & I55 & 180 & $4 \cdot 1$ & $\begin{array}{l}\text { Agricultural Research Council } \\
\text { (198I) }\end{array}$ \\
\hline $\begin{array}{l}\text { Suckler cow } \\
\text { Dairy cow }\end{array}$ & $\begin{array}{l}570 \\
600\end{array}$ & $\begin{array}{r}700 \\
1000\end{array}$ & $\begin{array}{l}6 \cdot 0 \\
8 \cdot 2\end{array}$ & $\begin{array}{l}\text { Trigg \& Topps ( } 1981 \text { ) } \\
\text { Bauman \& Currie (1980) }\end{array}$ \\
\hline
\end{tabular}

W, body-weight. 


\section{Rates of fat loss during lactation}

Some loss of body lipid is a general feature of lactation and in Table 2 an attempt is made to define its magnitude for a number of species. There is no evidence from the values in Table 2 that the higher metabolic demands that lactation tends to place on small compared with large species (Hanwell \& Peaker, 1977) is reflected in their greater dependence on maternal lipid reserves. There is a number of reasons for this. Small mammals show an enormous increase in appetite during lactation; greater relatively than, for example, the dairy cow. Furthermore, the values in Table 2 are more of a reflection of current diet formulations and nutritional practices than of any innate expression of lipid mobilization by each species. In the case of the dairy cow there is the added complication of many years of genetic selection for milk yield. This creates a demand for nutrients in early lactation that is beyond the current capacity of the digestive tract to produce. Robinson et al. (1978) have drawn attention to a similar gap between the nutrient needs of the gravid uterus of the highly-prolific ewe in late pregnancy and her voluntary food consumption. For these reasons the formulation of feeding strategies for the manipulation of body lipid reserves on a total reproductive-cycle basis, without compromising the well-being of the animal, is the real challenge to the nutritionist.

The author thanks Dr. V. R. Fowler for helpful discussions in preparing this manuscript.

\section{REFERENCES}

Agricultural Research Council (r980). The Nutrient Requirements of Ruminant Livestock. Slough: Commonwealth Agricultural Bureaux.

Agricultural Research Council (198r). The Nutrient Requirements of Pigs. Slough: Commonwealth Agricultural Bureaux.

Anderson, D. M., Elsley, F. W. H. \& McDonald, I. (1970). Quarterly Fournal of Physiology 55, 293-300.

Anderson, R. R. (1975). Journal of Animal Science 41, $118-123$.

Barcroft, J., Kennedy, J. A. \& Mason, M. F. (1939). Journal of Physiology, London 95, 159-1 72.

Bauman, D. E. \& Currie, W. B. (1980). Journal of Dairy Science 63, $15^{14-1} 529$.

Blaxter, K. L. (1964). In Mammalian Protein Metabolism, 2, pp. 173-223 [H. N. Munro and J. B. Allison, editors]. London: Academic Press.

Blaxter, K. L. (1971). In Lactation, pp. $5^{1-69}$ [I. R. Falconer, editor]. London: Butterworths.

Boyne, R., Fell, B. F. \& Robb, I. (1966). Fournal of Physiology 183, 570-575.

Campbell, R. M. \& Fell, B. F. (1970). Research in Veterinary Science I1, 540-547.

Campbell, R. M., Fell, B. F. \& Mackie, W. S. (1974). Journal of Physiology 24I, 699-71 3.

Close, W. H., Noblet, J. \& Heavens, R. P. ( 1985 ). British fournal of Nutrition 53, 267-279.

Cowan, R. T., Robinson, J. J., Greenhalgh, J. F. D. \& McHattie, I. (1979). Animal Production 29, $8 \mathrm{r}-90$.

Cowan, R. T., Robinson, J. J. \& McDonald, I. (1982). Animal Production 34, 355-357.

Cowan, R. T., Robinson, J. J., McDonald, I. \& Smart, R. (1980). Fournal of Agricultural Science, Cambridge 95, 497-514.

Cowan, R. T., Robinson, J. J., McHattie, I. \& Pennie, K. (1981). Animal Production 33, I I I-I 20. 
Degan, A. A. \& Young, B. A. (1980). Fournal of Agricultural Science, Cambridge 95, I-5.

Duffus, G. M., MacGillivray, I. \& Dennis, K. J. (1971). Fournal of Obstetrics and Gynaecology of the British Commonwealth 78, 97-104.

Elsley, F. W. H., Anderson, D. M., McDonald, I., MacPherson, R. M. \& Smart, R. (1966). Animal Production 8, $391-400$.

Faichney, G. J. \& White, G. A. (1980). Proceedings of the Australian Society of Animal Production 13, 455.

Fell, B. F. \& Campbell, R. M. (1974). Journal of Agricultural Science, Cambridge 82, 287-294.

Fell, B. F., Campbell, R. M. \& Boyne, R. (1964). Research in Veterinary Science 5, 1 75-185.

Fell, B. F., Campbell, R. M., Mackie, W. S. \& Weekes, T. E. C. (1972). Fournal of Agricultural Science, Cambridge 79, 397-407.

Fell, B. F., Smith, K. A. \& Campbell, R. M. (1963). Fourmal of Pathology and Bacteriology 85, 179-188.

Field, A. C., Suttle, N. F. \& Gunn, R. G. (1968). Fournal of Agricultural Science, Cambridge 71, 303-310.

Foot, J. Z. (1969). Journal of Reproduction and Fertility 9, Suppl. 9-16.

Foot, J. Z., Skedd, E. \& McFarlane, D. N. (1979). Fournal of Agricultural Science, Cambridge 92, 69-81.

Gonzalez, J. S., Robinson, J. J. \& Fraser, C. (1985). Livestock Production Science 12, 59-68.

Hanwell, A. \& Peaker, M. (1977). Symposium of the Zoological Society, London no. 41, 297-312.

Heap, F. C. \& Lodge, G. A. (1967). Animal Production 9, 237-246.

Hovell, F. D. DeB., MacPherson, R. M., Crofts, R. M. J. \& Pennie, K. (1977). Animal Production $25,233-245$.

Hytten, F. E. \& Leitch, I. (1971). The Physiology of Human Pregnancy, 2nd ed. Oxford: Blackwell Scientific Publications.

Hytten, F. E. \& Paintin, D. B. (I $\left.96_{3}\right)$. Fournal of Obstetrics and Gynaecology of the British Commonwealth 70, 402-407.

Johnson, C. L. (1973). Yournal of Endocrinology 56, 37-46.

Kanto, U. \& Clawson, A. J. (1980). Fournal of Nutrition 110, 1829-1839.

Knopp, R. H., Saudek, C. D., Arky, R. A. \& O'Sullivan, J. B. (1973). Endocrinology 92, 984-988.

Little, W. \& Kay, R. M. (1979). Animal Production 29, 13 I-142.

Lodge, G. A., Friend, D. W. \& Wolynetz, M. S. (I979). Canadian Fournal of Animal Science 59, $5 \mathrm{I}-6 \mathrm{I}$.

Lodge, G. A. \& Heaney, D. P. (1973). Canadian fournal of Animal Science 53, 479-489.

Milner, C. \& Gwynne, D. (1974). In Island Survivors, pp. 273-325 [P. A. Jewell, C. Milner, and J. Morton, editors]. Athlone Press: University of London.

Mitchell, B., McCowan, D. \& Nicholson, I. A. (1976). Fournal of the Zoological Society of London 180, 107-127.

Moore, B. J. \& Brasel, J. A. (1984). Fournal of Nutrition 114, $1560-1565$.

Moore, B. J., Olsen, J. L., Marks, F. \& Brasel, J. A. (1984). Fournal of Nutrition II4, $1566-1573$.

Naismith, D. J. (1969). Proceedings of the Nutrition Society 28, 25-31.

Naismith, D. J. \& Morgan, B. L. G. (1976). British Fournal of Nutrition 36, 563-566.

Naismith, D. J., Richardson, D. P. \& Pritchard, A. E. (1982). British fournal of Nutrition 48, 433-44I.

Partridge, G. G., Fuller, M. F. \& Pullar, J. D. (1983). British fournal of Nutrition 49, 507-5 16.

Reynolds, M. (1953). American Journal of Physiology $175,118-122$.

Robinson, J. J. (1977). Proceedings of the Nutrition Society 36, 9-16.

Robinson, J. J., McDonald, I., McHattie, I. \& Pennie, K. (1978). Fournal of Agricultural Science, Cambridge 91, 291-304.

Rombauts, P. (1959). Compte rendu de l'Academie des sciences 248, 1859-1862.

Rosso, P. \& Streeter, M. R. (1979). Foumal of Nutrition 109, 1887-1892.

Russel, A. J. F., Gunn, R. G. \& Doney, J. M. (1968). Animal Production 10, 43-51.

Saimon-Legagneur (1965). Annals Zootechnique 14, I-I37.

Shields, R. G. \& Mahan, D. C. (1983). Fournal of Animal Science 57, 594-603.

Sykes, A. R. \& Field, A. C. (1974). Fournal of Agricultural Science, Cambridge 83, 161-169.

Sykes, A. R. \& Geenty, K. G. (1985). Fournal of Agricultural Science, Cambridge (In the Press).

Sykes, A. R., Nisbet, D. I. \& Field, A. C. (1973). Fournal of Agricultural Science, Cambridge 81, 433-440. 
Trigg, T. E. \& Topps, J. H. (1981). Journal of Agricultural Science, Cambridge 97, $147^{-1} 57$.

Vernon, R. G. \& Flint, D. J. (1984). Symposium of the Zoological Society, London no. 5 r, $119-145$.

Widdowson, E. M. (1976). Breast Feeding and the Mother. Ciba Foundation Sympasium no. 45, 103-I 18.

Widdowson, E. M. (1981). In Environmental Factors in Mammal Reproduction, pp. 145-159 [D. Gilmore and B. Cook, editors]. London: Macmillan.

Zartarian, G. N., Galler, J. R. \& Munro, H. N. (1980). Fournal of Nutrition 110, $1291-1297$.

Zoiopoulos, P. E., Topps, J. H. \& English, P. R. (1983). British Yournal of Nutrition 50, 163-172. 